\title{
Antioxidant and gastroprotective effects of the ethyl acetate extract from Stemodia maritima L. in ethanol-induced gastric ulcer model
}

\author{
Efeitos antioxidante e gastroprotetor do extrato acetato de etila de Stemodia maritima L em modelo \\ de úlcera gástrica induzida por etanol
}

Efectos antioxidante y gastroprotector del extracto de acetato de etilo de Stemodia maritima L. en el modelo de úlcera gástrica inducida por etanol

Received: 10/30/2021 | Reviewed: 11/07/2021 | Accept: 11/14/2021| Published: 11/24/2021

\author{
Rayane Siqueira de Sousa \\ ORCID: https://orcid.org/0000-0003-0529-4274 \\ Federal University of Pernambuco, Brazil \\ E-mail: rayane-siqueira@hotmail.com.br \\ Jéssica de Andrade Gomes Silva \\ ORCID: https://orcid.org/0000-0003-0481-2164 \\ Federal University of Pernambuco, Brazil \\ E-mail: jessica.andrade.gs@gmail.com \\ Elizabeth Fernanda de Oliveira Borba \\ ORCID: https://orcid.org/0000-0003-1460-027X \\ Federal University of Pernambuco, Brazil \\ E-mail: elizabethfernanda_7@hotmail.com \\ Katharina Rodrigues de Lima Porto Ramos \\ ORCID: https://orcid.org/0000-0001-7747-144X \\ Federal University of Pernambuco, Brazil \\ E-mail: khatarinaporto@gmail.com \\ Camila Joyce Alves da Silva \\ ORCID: https://orcid.org/0000-0003-2013-1123 \\ Federal University of Pernambuco, Brazil \\ E-mail: camilaalvesmendes@hotmail.com \\ Persio Alexandre da Silva \\ ORCID: https://orcid.org/0000-0002-6281-4515 \\ Federal University of Pernambuco, Brazil \\ E-mail: persiosilva@gmail.com \\ Marília Grasielly de Farias Silva \\ ORCID: https://orcid.org/0000-0001-9324-0027 \\ Federal University of Pernambuco, Brazil \\ E-mail: marilia8921@hotmail.com \\ Bárbara de Azevedo Ramos \\ ORCID: https://orcid.org/0000-0002-1166-8183 \\ Federal University of Pernambuco, Brazil \\ E-mail: barbara.azevedo@ufpe.br \\ Raudiney Frankilin Vasconcelos Mendes \\ ORCID: https://orcid.org/0000-0003-3968-2259 \\ Federal University of Pernambuco, Brazil \\ E-mail: raudiney.mendes@ufpe.br \\ Teresinha Gonçalves Silva \\ ORCID: https://orcid.org/0000-0002-5971-0029 \\ Federal University of Pernambuco, Brazil \\ E-mail: teresinha100@gmail.com
}

\begin{abstract}
Stemodia maritima L., is a shrub of the Plantaginaceae family, with some biological activities already described, such as: larvicide, antimicrobial, and anti-inflammatory. Thus, the objective of this work was to evaluate the antioxidant, and gastroprotective activities of the ethyl acetate extract from $S$. maritima. The phytochemical profile was investigated through the quantification of total phenolic compounds, flavonoids, and CCD analysis. The toxicity of the extract was performed through cell viability using L929 line cell, and acute toxicity by the OECD Guide 423. The antioxidant activity was analyzed by the methods of reduction of the ferric ion (FRAP), total antioxidant activity (TAA), and the gastroprotective activity by the absolute ethanol-induced gastric ulcer model, with analysis of NO, MDA, GSH and MPO levels in the stomach tissues. In the phytochemical profile it was possible to identify the presence of flavonoids, triterpenes, steroids, mono, and sesquiterpenes. The extract was not cytotoxic against L929
\end{abstract}


lineage, maintaining cell viability above $70 \%$ at the doses tested, and in acute toxicity it did not show physiological changes indicative of toxicity compared to the control group. The extract presented antioxidant activity of $157.3 \pm 9.7$ $\mathrm{mg}$ equivalent of Trolox/g of extract in the FRAP method, and $50.0 \pm 1.1 \%$ by TAA. The ethyl acetate extract of $S$. maritima, at the doses tested, reduced the ulcerative lesion index compared to the injured control group, increased the levels of NO and GSH, and was able to decrease the concentrations of MDA and MPO, enhancing their gastroprotective activity.

Keywords: Antiulcer; Phenolic compounds; Cytotoxicity; Oxidative stress.

\section{Resumo}

Stemodia maritima L., é um arbusto da família Plantaginaceae, com algumas atividades biológicas já descritas, como: larvicida, antimicrobiana e anti-inflamatória. Portanto, o objetivo deste trabalho foi avaliar as atividades antioxidante e gastroprotetora do extrato acetato de etila de $S$. maritima. O perfil fitoquímico foi investigado através da dosagem de compostos fenólicos totais, flavonoides e análise por CCD. A toxicidade do extrato foi feita por meio da análise de viabilidade celular com linhagem L929 e a toxicidade aguda pelo Guia OECD 423. A atividade antioxidante foi analisada pelos métodos de redução do íon férrico (FRAP) e atividade antioxidante total (AAT), e a atividade gastroprotetora pelo modelo de úlcera gástrica induzida por etanol absoluto, com avaliação dos níveis de NO, MDA, GSH e MPO nos tecidos dos estômagos. No perfil fitoquímico foi possível identificar a presença de flavonoides, triterpenos, esteroides, mono e sesquiterpenos. O extrato não foi citotóxico frente à linhagem L929, mantendo a viabilidade celular acima de $70 \%$ nas doses testadas, e na toxicidade aguda não apresentou alterações fisiológicas indicativas de toxicidade em comparação com o grupo controle. O extrato apresentou atividade antioxidante de 157,3 \pm 9,7 mg equivalente de Trolox/g de extrato no método de FRAP, e de 50,0 $\pm 1,1 \%$ pelo AAT. O extrato acetato de etila de $S$. maritima, nas doses testadas, reduziu o índice de lesão ulcerativa em relação ao grupo controle lesionado, aumentou os níveis de NO e GSH e foi capaz de diminuir as concentrações de MDA e MPO, acentuando sua atividade gastroprotetora.

Palavras-chave: Antiúlcera; Compostos fenólicos; Citotoxicidade; Estresse oxidativo.

\section{Resumen}

Stemodia maritima L., es un arbusto de la familia Plantaginaceae, con algunas actividades biológicas ya descritas, tales como: larvicidas, antimicrobianas y antiinflamatorias. Así que, el objetivo de este trabajo fue evaluar las actividades antioxidantes y gastroprotectoras del extracto de acetato de etilo de $S$. marítima. El perfil fitoquímico se investigó a través de la dosificación de compuestos fenólicos totales, flavonoides y análisis de CCD. La toxicidad del extracto se realizó a través de la viabilidad celular con L929 y toxicidad aguda utilizando la Guía 423 de la OCDE. La actividad antioxidante se analizó mediante los métodos de reducción del ion férrico (FRAP) y la actividad antioxidante total (AAT), y la actividad gastroprotectora por el modelo de úlcera gástrica inducida por etanol absoluto, con evaluación de niveles de NO, MDA, GSH y MPO de los tejidos estomacales. En el perfil fitoquímico fue posible identificar flavonoides, triterpenos, esteroides, mono y sesquiterpenos. El extracto no fue citotóxico contra el linaje L929, manteniendo la viabilidad celular por encima del 70\% en las dosis probadas y en la toxicidad aguda no mostró cambios fisiológicos que indicaran toxicidad en comparación con el control. El extracto presentó una actividad antioxidante de 157,3 \pm 9,74 mg equivalentes de Trolox/g de extracto en el método FRAP y 50,0 $\pm 1,1 \%$ por AAT. El extracto de acetato de etilo de $S$. maritima, a las dosis probadas, redujo el índice de lesión ulcerosa en relación con el grupo control lesionado, aumentó los niveles de NO y GSH y fue capaz de disminuir las concentraciones de MDA y MPO, destacando su actividad gastroprotectora.

Palabras clave: Antiúlcera; Compuestos fenólicos; Citotoxicidad; Estrés oxidativo.

\section{Introduction}

The gastric ulcer, which appears in the stomach mucosa, presents as inflammatory or necrotizing lesions causing pain, bleeding, obstruction, and even perforations that can progress to death. Currently, gastric ulcers affect about $10 \%$ of the world population, and are the target of scientific investigations due to this frequency, and concern in clinical practice (Lanas \& Chan, 2017; Farrag et al., 2019). Gastric ulcer occurs due to an imbalance between aggressive and protective factors of the gastric mucosa. Among aggressive factors, can be described endogenous and exogenous factors, such as high secretion of gastric acid, and pepsin, inhibition of mucosal cell proliferation, reduced blood flow, suppression of prostaglandins, excessive alcohol intake habits, stress, Helicobacter pylori infection, and prolonged use of nonsteroidal anti-inflammatory drugs (NSAIDs). Factors related to protection include bicarbonate and mucus secretion, gastroprotective prostaglandin biosynthesis, nitric oxide, adequate tissue blood microcirculation, and antioxidant agents. The imbalance between aggressive and protective factors triggers to oxidative stress by the formation of oxidizing substances, increasing the production of pro-inflammatory cytokines, 
reducing blood flow and cell viability, and promoting the appearance of gastric lesions (Cook \& Guyatt, 2018; Kavitt et al., 2019).

Treatments for gastric ulcers mainly include histamine H2-receptor antagonist drugs, proton pump inhibitors, and antacids. However, they are not fully effective methods of cure, as they act only to relieve symptoms, and there is a high rate of relapse after treatment interruption, which may also be related to serious side effects (Kavitt et al., 2019).

The use of medicinal plants to treat various disorders is an ancient practice inherited over several generations, thus, is an increasingly explored source. In addition to medicinal plants known for their pharmacological properties, it is common to carry out pre-clinical research on plants or their metabolites as potential therapeutic sources in the treatment of diseases, or selected as candidates for new drugs (Safavi et al., 2015).

Stemodia maritima L. is a shrub of the Plantaginaceae family, common in northeastern Brazil, where it can be found in marshy regions by the name of "matruz-bravo", "melosa" or "meladinha" (Rodrigues et al., 2010; Moreira \& Bragança, 2011). Chemical studies report the presence of flavonoids, diterpenes and polyphenols, and some related biological activities, such as larvicide (Arriaga et al., 2007), antioxidant, antimicrobial (SILVA et al, 2014), and anti-inflammatory (Texeira et al., 2017). There are also reports of antiviral, and cytotoxic activities of analogues derived from crenatoside and stemodin, respectively, compounds that can be found in S. maritima (Chen et al., 2016; RUSSEL et al., 2011).

Despite these data, there are no reports of specific studies for gastric ulcer inflammation with S. maritima L. extract or its bioactive metabolites. Therefore, this work aimed to investigate the in vivo gastroprotective and antioxidant activities of the ethyl acetate extract of S. maritima leaves (AcSm), analyze the phytochemical profile and toxicity, as well as contribute for enriching the scientific community, as our group is a pioneer in the study of gastroprotection of this species.

\section{Methodology}

This study is an experimental scientific investigation, the research project was approved by the Ethics Committee in the Use of Animals at the Federal University of Pernambuco - UFPE, under protocol 134/2019.

\subsection{Animals}

Swiss mice (Mus musculus), female (25-30 g), and Wistar rats (Rattus norvergicus), male (250-280 g), from the Animal Facility of the Department of Antibiotics of UFPE, Campus Recife, Pernambuco, Brazil were used. The animals were kept under appropriate conditions, following the guidelines of the National Council for the Control of Animal Experimentation (NCCAE), and the method to perform euthanasia was an anesthetic overdose: Ketamine $(0.2 \mathrm{~mL} / 100 \mathrm{~g}+0.2 \mathrm{~mL} / 100 \mathrm{~g}$ overdose) and xylazine $(0.1 \mathrm{~mL} / 100 \mathrm{~g}+0.1 \mathrm{~mL} / 100 \mathrm{~g}$ overdose) intraperitoneal route (i.p.).

\subsection{Obtaining the plant extract}

The leaves of S. maritima (794 g) were collected in the municipality of Boqueirão - PB (coordinates: latitude 7.4824 and longitude -36,1223) and botanical identification was performed at the Herbarium of the Agronomic Institute of Pernambuco (IPA) by specialist Olivia Cano, with the number of catalog 92093. Ethyl acetate extract (AcSm) was obtained by exhaustive maceration, under agitation and at room temperature, for three cycles with solvent change every 72 hours. The solvent was totally removed with the aid of a rotary evaporator at low pressure to obtain the AcSm extract. 


\subsection{Phytochemical profile}

\subsubsection{Thin layer chromatographic (TLC) analysis}

AcSm was weighed and dissolved in methanol at a concentration of $5 \mathrm{mg} / \mathrm{mL}$. As the fixed phase, $\mathrm{F}_{254}$ silica gel plates were used and as mobile phases specific eluting and developer systems for flavonoids, cinnamic derivatives, phenylpropane glycosides (AcOEt-HCOOH-AcOH-H $2 \mathrm{O}(100: 11: 11: 27 \mathrm{v} / \mathrm{v})$, standards: quercetin, rutin and chlorogenic acid, NEU reagent ethylborilaminoester acid); for triterpenes and steroids (Toluene:AcOEt (90:10 v/v), standard: $\beta$-sitosterol, Lieberman \& Burchard reagent), mono and sesquiterpenes (Toluene:AcOEt (97:3 v/v), standard: timol, sulphuric anisaldehyde reagent), for alkaloids (AcOEt-HCOOH-AcOH-H2O (100:11:11:27 v/v), pattern: pilocarpin, Dragendorff reagent), and for condensed proanthocyanidins and leucoanthocyanidin (AcOEt-HCOOH-AcOH$-\mathrm{H}_{2} \mathrm{O}(100: 11: 11: 27 \mathrm{v} / \mathrm{v})$, standard: catechin, vanillin/HCl reagent).

\subsubsection{Dosage of total phenolic compounds}

According to the methodology proposed by Li et al. (2008), the dosage of total phenolic compounds in AcSm was determined using the Folin-Ciocalteu reagent, in triplicate. This test is based on the formation of a blue complex, by reduction of the reagent by the phenolic hydroxyls present in the sample. AcSm $(1 \mathrm{mg})$ was added to $1 \mathrm{ml}$ of Folin-Ciocalteu reagent (1:1 $\mathrm{v} / \mathrm{v}$ ) and the mixture was allowed to stand (protected from light) for 3 minutes. Then, $0.8 \mathrm{ml}$ of $7.5 \%$ sodium carbonate was added and the mixture was incubated for 120 minutes in a dark environment. Absorbances were read in a spectrophotometer at $765 \mathrm{~nm}$. Gallic acid $(0-500 \mathrm{mg} / \mathrm{L})$ was used to calibrate the standard curve and the results were expressed in milligrams equivalent of gallic acid (mg EAG)/g of extract.

\subsubsection{Flavonoid dosage}

Flavonoid content was quantified by the technique described by Pekal \& Pyrzynska (2014), where $100 \mu \mathrm{L}$ of AcSm, blank (solvent used to dilute $\mathrm{AcSm}$ ) or quercetin concentrations were added to $0.05 \mathrm{~mL}$ of aluminum chloride reagent $(2 \%)$ and $0.05 \mathrm{~mL}$ of sodium acetate $(1 \mathrm{M})$. Another blank was performed for each sample $(0.1 \mathrm{~mL}$ of sample $+0.1 \mathrm{~mL}$ of distilled water), to subtract the absorbance value of the diluted samples, to avoid false positives. The samples were shaken and kept at room temperature for 10 minutes, then absorbances were measured at $425 \mathrm{~nm}$ and the total flavonoid content in the extracts was expressed as quercetin equivalent (mg EQ/g extract).

\subsection{In vitro antioxidant activity}

\subsubsection{Ferric ion reducing activity (FRAP)}

The FRAP assay was performed according to Benzie \& Strain (1996). The stock solution was prepared with $300 \mathrm{mM}$ acetate buffer, $10 \mathrm{mM}$ TPTZ (2,4,6-tripyridyl-s triazine) solubilized in $40 \mathrm{mM} \mathrm{HCl}$, and $20 \mathrm{mM} \mathrm{FeCl}_{3}$ solution. The working solution was prepared with $25 \mathrm{~mL}$ of acetate buffer, $2.5 \mathrm{~mL}$ of TPTZ, and $2.5 \mathrm{~mL} \mathrm{FeCl}_{3}$ (10:1:1), and incubated for $5 \mathrm{~min}$ at 37 ${ }^{\circ} \mathrm{C}$. A volume of $10 \mu \mathrm{L}$ of AcSm at a concentration of $1 \mathrm{mg} / \mathrm{mL}$ was mixed with $290 \mu \mathrm{L}$ of FRAP reagent, and left to stand for 15 minutes at $37{ }^{\circ} \mathrm{C}$ in the dark. Subsequently, absorbances were measured at $593 \mathrm{~nm}$. Quercetin was used as an antioxidant reference, and a standard curve with Trolox $(0-2000 \mu \mathrm{g} / \mathrm{mL})$ was obtained. The results were expressed in equivalent $\mathrm{mg}$ of Trolox/g of extract (ET/g).

\subsubsection{Total antioxidant activity (TAA)}

The total antioxidant activity was measured according to Prieto et al. (1999). The $100 \mu \mathrm{L}$ volume of AcSm at the concentration of $1 \mathrm{mg} / \mathrm{mL}$ was mixed with $1 \mathrm{~mL}$ of the phosphomolybdenum solution (600 mM sulfuric acid, $28 \mathrm{mM}$ sodium 
phosphate and $4 \mathrm{mM}$ ammonium molybdate). Samples were incubated at $95{ }^{\circ} \mathrm{C}$ for 90 minutes. After returning to room temperature, absorbances were measured at $695 \mathrm{~nm}$ against a blank ( $1 \mathrm{~mL}$ of solution and $100 \mu \mathrm{L}$ of sample dilution solvent). Quercetin was used as a reference control and TAA was expressed in relation to the ascorbic acid standard and calculated by the formula:

$$
\text { TAA }(\%)=\frac{\text { Sample absorbance }- \text { White absorbance }}{\text { Standard Absorbance }- \text { White Absorbance }} 100
$$

\subsection{Cell viability assay}

AcSm was submitted to cell viability colorimetric assay, based on the mitochondrial activity of cells by the reduction of 3-(4,5-dimethyl-2-thiazolyl)-2,5-diphenyl-2H-tetrazolium bromide (MTT) (Mosmann, 1983). Fibroblasts of the L929 lineage were used, these were treated with AcSm at concentrations from 1.56 to $50 \mu \mathrm{g} / \mathrm{mL}$ for 72 hours and kept in an oven at $5 \% \mathrm{CO}_{2}$. After $72 \mathrm{~h}$ of incubation, $25 \mu \mathrm{L}$ of MTT $(5 \mathrm{mg} / \mathrm{mL})$ was added and after $3 \mathrm{~h}$, the culture media with the MTT was aspirated and $100 \mu \mathrm{L}$ of DMSO was added. Absorbance was measured in a microplate reader at a wavelength of $560 \mathrm{~nm}$.

\subsection{Acute toxicity}

AcSm acute toxicity was performed according to OECD Guide 423 (OECD, 2001). The mice were divided into two groups according to their single-dose treatment: control (aqueous solution of Tween 20 at $1 \%$ ) and AcSm 2,000 mg/kg (by gavage) and behavioral parameters were observed during the first hours after treatment. Feed/water consumption and body mass gain were measured daily until the $14^{\text {th }}$ day. After the last analysis, the animals received a dose of anesthetic, and blood was collected by cardiac puncture for biochemical and hematological analysis. After euthanasia, livers, kidneys, and spleen were dissected for macroscopic analysis of signs of toxicity.

\subsection{Absolute ethanol-induced gastric injury}

The rats were randomly divided into 6 groups $(n=6)$, fasted for $18 \mathrm{~h}$ and then treated with their respective substances: Healthy control - HC (no ethanol administration, treated with aqueous solution with Tween 20 at $1 \%$ ), Injured control - IC (received absolute ethanol and was treated with aqueous solution with Tween 20 at 1\%), Lansoprazole (30 $\mathrm{mg} / \mathrm{kg}$ ), AcSm 25, 50 and $100 \mathrm{mg} / \mathrm{kg}$ through gavage. After 1 hour of treatment, the animals were induced to gastric injury with the administration of absolute ethanol ( $4 \mathrm{~mL} / \mathrm{kg}$ through gavage). One hour after this administration, the rats were euthanized and their stomachs removed, washed with saline solution, opened by the greater curvature, and photographed. Ulcerative Lesions Index (ULI) calculations were performed using computerized planimetry (Software ImageJ) (Morimoto et al., 1991).

\subsection{Determination of nitric oxide (NO) levels}

The concentration of nitrite in the stomach homogenate $(100 \mathrm{mg} / \mathrm{mL}$ in $150 \mathrm{mM}$ phosphate buffer, $\mathrm{pH} 7.4)$ was used as an index of NO production through the Griess reaction, where $50 \mu \mathrm{L}$ of the sample was incubated for 10 min with $50 \mu \mathrm{L}$ of Griess solution, protected from light. Absorbance was measured at a wavelength of $560 \mathrm{~nm}$ using a microplate reader and the concentration of nitrite was determined by comparing the absorbance of the sample to a standard curve for sodium nitrite (Green et al., 1981). 


\subsection{Determination of malondialdehyde (MDA) levels}

The degree of lipid peroxidation was estimated by determining MDA levels through the thiobarbituric acid reactive substances test (TBARS), using the method described by Draper \& Hadley (1990). Tissues were homogenized (100 mg/mL) in $150 \mu \mathrm{M}$ phosphate buffer ( $\mathrm{pH}$ 7.4). After homogenization, the samples were mixed with $1 \mathrm{~mL}$ of $10 \%$ trichloroacetic acid and centrifuged at $10000 \mathrm{rpm} / 15 \mathrm{~min} / 4{ }^{\circ} \mathrm{C}$. Then, the supernatant was incubated with $500 \mu \mathrm{L}$ of $1.2 \%$ thiobarbituric acid. The mixture was brought to the boiling water bath $\left(95^{\circ} \mathrm{C} / 30 \mathrm{~min}\right)$. After the samples had cooled down, they were placed in a 96 well plate and read using a microplate reader $(535 \mathrm{~nm})$. The results were expressed in $\mathrm{nmol}$ of MDA/mg tissue.

\subsection{Determining Reduced Glutathione Levels (GSH)}

The determination of GSH concentration is based on the reaction of Ellman's reagent, 5,5'-dithiobis (2-nitrobenzoic acid) (DTNB), with the free thiol, resulting in a mixed disulfide plus 2-nitro-5 acid -thiobenzoic, whose measurement of the reaction product formed is made by spectrophotometric reading. For the quantification of GSH, the glandular portion of the stomachs was homogenized in EDTA $0.02 \mathrm{M}(1 \mathrm{~mL} / 100 \mathrm{mg}$ of tissue). An aliquot of $40 \mu \mathrm{L}$ of this homogenate $+50 \mu \mathrm{L}$ of distilled water $+10 \mu \mathrm{L}$ of trichloroacetic acid $50 \%$ was stirred and centrifuged at $5000 \mathrm{rpm} / 15 \mathrm{~min} / 4^{\circ} \mathrm{C}$. Then, $60 \mu \mathrm{L}$ of the supernatant was collected, and $25 \mu \mathrm{L}$ of Tris buffer $0.4 \mathrm{M}$ plus $20 \mu \mathrm{L}$ of DTNB $0.01 \mathrm{M}$ were added. After 1 minute of the reaction, the color reading was performed in a microplate reader at $412 \mathrm{~nm}$ (Sedlak \& Lindsay, 1968).

\subsection{Determination of myeloperoxidase levels (MPO)}

The stomachs were homogenized $(1 \mathrm{~mL} / 100 \mathrm{mg}$ of tissue) in a $0.5 \%$ hexadecyltrimethylammonium bromide (HTAB) solution. The myeloperoxidase activity was evaluated according to the protocol described by Bradley et al. (1982), by reacting the samples with $200 \mu \mathrm{L}$ of reaction solution (o-dianisidine hydrochloride $-0.167 \mathrm{mg} / \mathrm{mL}, 50 \mathrm{mM}$ sodium phosphate buffer, and $0.0005 \%$ hydrogen peroxide). After incubation, the reaction was read in a microplate reader at a wavelength of $450 \mathrm{~nm}$.

\subsection{Statistical analysis}

Data were subjected to analysis of variance (one-way ANOVA), followed by Tukey's test. For cytotoxic activity, Bonferroni was used as a post-test, and for acute toxicity and antioxidants, the t-test was used. All numerical values were presented as mean \pm standard deviation of the mean (SD) and $\mathrm{p}<0.05$ values were considered significant. Analyzes were performed using the GraphPad Prism software, version 8.0 (San Diego, CA, EUA).

\section{Results and Discussion}

\subsection{Phytochemical profile analysis}

Analysis by CCD indicated the presence of flavonoids, triterpenes and steroids, mono and sesquiterpenes in AcSm (Table 1). 
Table 1 - Classes of secondary metabolites found in AcSm via CCD.

\begin{tabular}{ll}
\hline Secondary metabolites & AcSm \\
\hline Flavonoids & + \\
Phenylpropanoids & - \\
Triterpenes and steroids & ++ \\
Mono and sesquiterpenes & ++ \\
Proanthocyanidins and leucoanthocyanidins & - \\
Anthocyanins and anthocyanidins & - \\
Hydrolyzable tannins & - \\
\hline
\end{tabular}

Subtitle: (-) absent; (+) weak; (++) medium; (+++) strong. Source: Authors.

These data corroborate previous chemical studies, where they found flavonoids and diterpenes in the composition of S. maritima. Other species of the genus also have phenolic compounds, steroid triterpenes and diterpenes abundance (Rodrigues et al., 2010; Silva et al., 2014).

After analysis by CCD, the content of total phenolic compounds and flavonoids was analyzed. AcSm presented, respectively, $71.25 \pm 3.54 \mathrm{mg}$ equivalent of gallic acid/g of extract and $6.97 \pm 2.06 \mathrm{mg}$ equivalent of quercetin/g of extract. Considerable levels of phenolic compounds are found in Veronica spicata (Dunkic et al., 2015), and Plantago lagopus (Harput et al., 2012), species that also belong to the Plantaginaceae family.

Flavonoids constitute the largest class of plant phenolics and can act as reducing agents, hydrogen donors, superoxide radical scavengers or metal chelating agents. As they are antioxidant substances, they are relevant compounds in several other biological activities, they can be divided into some classes, such as: flavonols, anthocyanins, isoflavonoids, flavanones, and flavones (Zakaria et al., 2016). Terpenes are another class of relevant compounds found in AcSm, they have a variety of activities, such as: anticancer, healing, antinociceptive, antimicrobial, anti-inflammatory, and gastroprotective activity (Choudhary et al., 2013; Chinedu \& Ibrahim, 2017).

\subsection{Evaluation of antioxidant activity}

In the ferric ion reduction assay, AcSm presented $157.3 \pm 9.7 \mathrm{mg}$ ET/g of extract while quercetin presented $551.57 \pm$ $17.49 \mathrm{mg} \mathrm{ET} / \mathrm{g}$ of the extract. In the total antioxidant activity assay, the ascorbic acid standard is considered the compound that has $100 \%$ activity, the AcSm extract showed $50.0 \% \pm 1.8$ of total antioxidant activity, a value close to quercetin which was $62.4 \% \pm 1.1$ (Table 2).

The antioxidant activity observed can be explained by the presence of phenolic compounds and flavonoids present in the extract, knowing that these substances have a high potential for reducing free radicals due to their chemical structures, where there are hydroxyl groups conjugated with aromatic rings, responsible for reactions that make the free radicals present in the media stable (Liu et al., 2013). There are no records in the literature regarding the antioxidant activity of these methods for S. maritima, however, Silva et al. (2014) described the antioxidant activity, by the DPPH method, of two compounds isolated from S. maritima, stemodin and crenatoside, where stemodin was not able to significantly sweep the DPPH radical and crenatoside showed potential action, with scanning of $99 \%$ of the radical at a concentration of $100 \mu \mathrm{g} / \mathrm{mL}$ and $\mathrm{IC}_{50}$ of 2.2 $\mu \mathrm{g} / \mathrm{mL}$. 
Table 2 - Evaluation of the antioxidant activity of AcSm by the FRAP and TAA method.

\begin{tabular}{ccc}
\hline Extract & $\begin{array}{c}\text { FRAP } \\
\text { equivalent } \mathbf{~ m g ~ o f ~ T r o l o x ~ ( E T / g ~} \\
\text { extract) }\end{array}$ & TAA (\%) \\
\hline AcSm & $157.3 \pm 9.7 *$ & $50.0 \pm 1.8^{*}$ \\
Quercetin & $551.6 \pm 17.5$ & $62.4 \pm 1.1$ \\
\hline
\end{tabular}

Subtitle: Results are expressed as mean \pm standard deviation. Analyzed by $t$ test, * indicate $p<0,0001$ in relation to the quercetin group. Source: Authors.

\subsection{Analysis of cell viability and acute toxicity}

AcSm cytotoxicity was analyzed before proceeding to in vivo tests, although cell cultures do not undergo the same physiological processes as animals, this in vitro test is commonly used to simulate, precede or even eliminate in vivo tests, as it is sensitive, fast, safe, and able to quantify cell viability after the treatment of new compounds ( $\mathrm{Li}$ et al., 2015; Hampshire \& Gilbert, 2018). In Figure 1, can be seen that AcSm did not show significant cytotoxicity against the L929 lineage, at concentrations ranging from 1.56 to $50 \mu \mathrm{g} / \mathrm{mL}$, maintaining cell viability, which indicates a certain safety for the start of in vivo testing.

Figure 1 - Effect of AcSm on the percentage of cell viability at concentrations from 1.56 to $50 \mu \mathrm{g} / \mathrm{mL}$ in fibroblast lineages (L929) using the MTT colorimetric method after 72 hours of treatment.

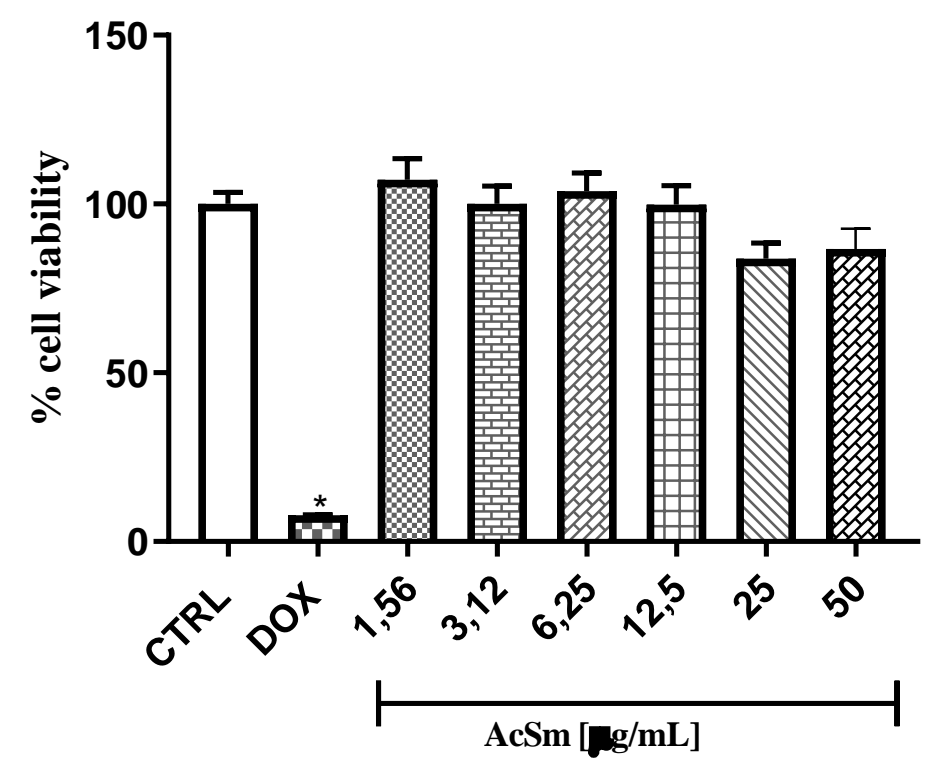

Subtitle: CTRL: control group - DMSO 1\%; DOX: Doxorubicin group $-5 \mu \mathrm{g} / \mathrm{mL}$; Results are expressed as mean \pm standard deviation. One way ANOVA analysis of variance, followed by Bonferroni test. * indicate $p<0,0001$ when compared the control group. Source: Authors.

After analyzing cell viability, the acute toxicity test was performed according to OECD 423 (2001). After the administration of substances in the AcSm group, the animals were observed to identify possible changes and signs indicative of toxicity. Initially, all three animals in the AcSm-treated group showed similar behavioral signs: agitation, piloerection, eyelid ptosis and excessive grooming. From the first hour, the animals were drowsy, but responded to touch.

During the 14 days of observation, the consumption of water, feed and body mass gain were evaluated, as shown in Table 3. There was no significant difference between the AcSm group and the control group. The reduction in body mass is a characteristic sign observed in most animals exposed to toxic substances, this is due to a variety of responses. Analyzing 
changes in the animal's body mass during exposure to exogenous substances is an important indicator of toxicity (Sangeetha et al., 2013).

Organs reveal metabolic changes caused by toxic substances, the characteristics of macroscopic changes, together with mass are relevant physiological indicators (Vaghasiya et al., 2011). The mass analysis of the dissected organs also did not reveal significant alterations indicative of toxicity (Table 4).

Table 3 - Effect of oral administration of AcSm and aqueous solution containing 1\% Tween 20 (control) on body mass gain and feed and water consumption in female mice, during 14 days of observation.

\begin{tabular}{ccc}
\hline Parameters & $\begin{array}{c}\text { Aqueous solution } \\
\text { containing 1\% } \\
\text { Tween 20 }\end{array}$ & $\begin{array}{c}\mathbf{A c S m} \\
(\mathbf{2 , 0 0 0} \mathbf{~ m g} / \mathbf{k g})\end{array}$ \\
\hline Feed consumption (g) & $19.50 \pm 2.10$ & $18.36 \pm 1.59$ \\
Water consumption (mL) & $31.79 \pm 2.69$ & $32.57 \pm 2.79$ \\
Body mass gain $(\mathrm{g})$ & $3.73 \pm 0.64$ & $3.03 \pm 0.25$ \\
\hline
\end{tabular}

Subtitle: Results are expressed as mean \pm standard deviation $(t$ test). Source: Authors.

Table 4 - Effect of oral administration of AcSm and aqueous solution containing 1\% Tween 20 (control) on organ mass (g) of female mice, during 14 days of observation.

\begin{tabular}{ccc}
\hline Organs (g) & $\begin{array}{c}\text { Aqueous solution } \\
\text { containing 1\% Tween }\end{array}$ & $\begin{array}{c}\mathbf{A c S m} \\
\mathbf{2 0}\end{array}$ \\
\hline Liver & $2.43 \pm 0.08$ & $2.24 \pm 0.08$ \\
Kidneys & $0.54 \pm 0.12$ & $0.60 \pm 0.12$ \\
Spleen & $0.29 \pm 0.06$ & $0.32 \pm 0.03$ \\
\hline
\end{tabular}

Subtitle: The results are expressed as mean \pm standard deviation $(t$ test). Source: Authors.

Hematological parameters were also analyzed, such as: red blood cells, hemoglobin, hematocrit, leukocytes, platelets, neutrophils, lymphocytes, monocytes, and eosinophils. The biochemical parameters analyzed was: urea, creatinine, TGO, TGP and uric acid. There was no significant difference between animal treated with AcSm when compared to the control group. Corroborating Texeira et al. (2017), where they demonstrated that values obtained for TGO/TGP and creatinine had no difference between the group treated with ethanol extract of $S$. maritima over 11 days and the control group. In that same study, the animals did not show toxicological signs, adverse effects, or behavioral changes, there was also no change in body mass and wet organ weight.

According to the guide's recommendations, in this study, the test was repeated $(n=3)$ under the same conditions and again there were no deaths. Thus, AcSm falls into category 5 (Lethal dose $-\mathrm{LD}_{50}>2,000 \mathrm{mg}$ or not estimated) of Guideline 423 (OECD, 2001).

\subsection{Evaluation of gastroprotective activity}

An experimental model widely used for preclinical evaluation of agents with potential gastroprotective activity is ethanol-induced gastric injury, since ethanol has been considered one of the causes of gastric ulcers in humans, and has rapid acute action in rodents (Song et al., 2018; Kavitt et al., 2019). In our study, the injured control group, which received vehicle and then absolute ethanol, had $76.5 \%$ of the injured area, the mucosas showed hemorrhage and necrosis, corroborating with other data, where ethanol was used as an inducing agent of gastric injury (Simões et al., 2019). 
Treatment with lansoprazole or AcSm doses significantly decreased ULI, all compared to the injured control. Lansoprazole preserved the mucosa and reduced 91\% of lesions, while AcSm at doses of 25, 50 and $100 \mathrm{mg} / \mathrm{kg}$ showed a reduction in the injured area of 81,85 , and $86 \%$, respectively. There was no significant difference between the doses tested (Figure 2). These results can also be seen through the macroscopic examination of the gastric mucosa, as shown in Figure 3.

These data corroborate the results obtained by Sousa et al. (2021), that observed the gastroprotective activity of the hexane extract of S. maritima leaves. Abud et al. (2012), described the gastroprotection of the methanol extract of Plantago major L., a species belonging to the same family as S. maritima, Plantaginaceae, and presenting similar compounds, such as polyphenols of the verbascoside type (Zubair et al., 2011).

Figure 2 - Effect of oral administration of AcSm on gastric lesions induced by absolute ethanol in rats.

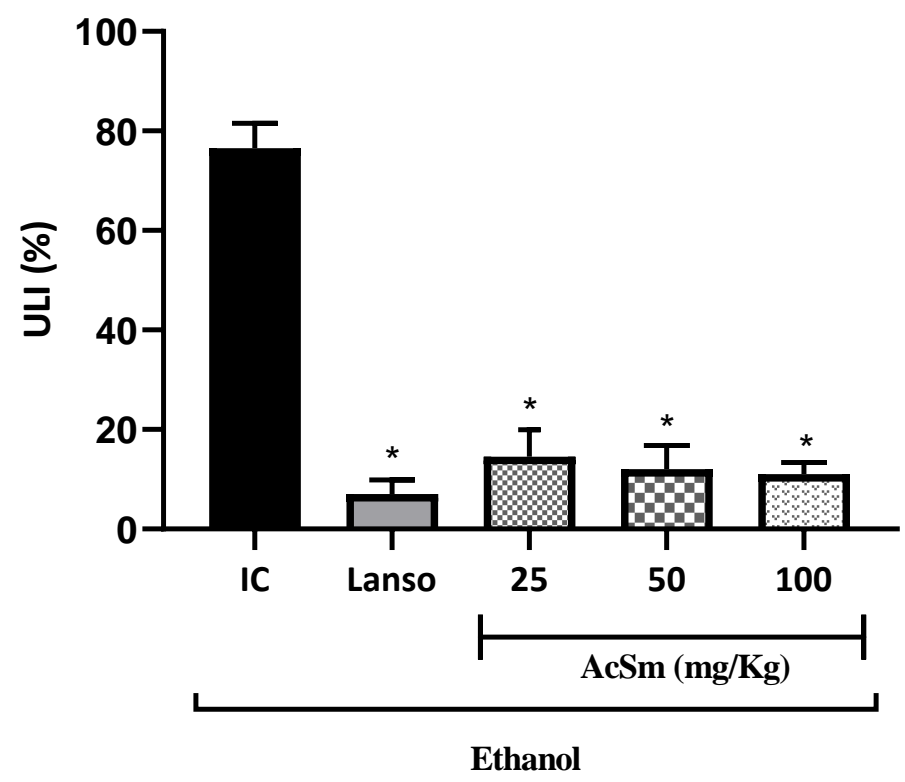

Subtitle: ULI - Ulcerative lesion index; IC - injured control; Lanso - lansoprazole $30 \mathrm{mg} / \mathrm{kg}$. Values are expressed as mean \pm SD. A one-way ANOVA followed by Tukey multiple-comparisons test. * indicate $p<0,0001$ in relation to the IC group. Source: Authors. 
Figure 3 - Macroscopic evaluation of the effect of AcSm on gastric lesions induced by absolute ethanol in rats.

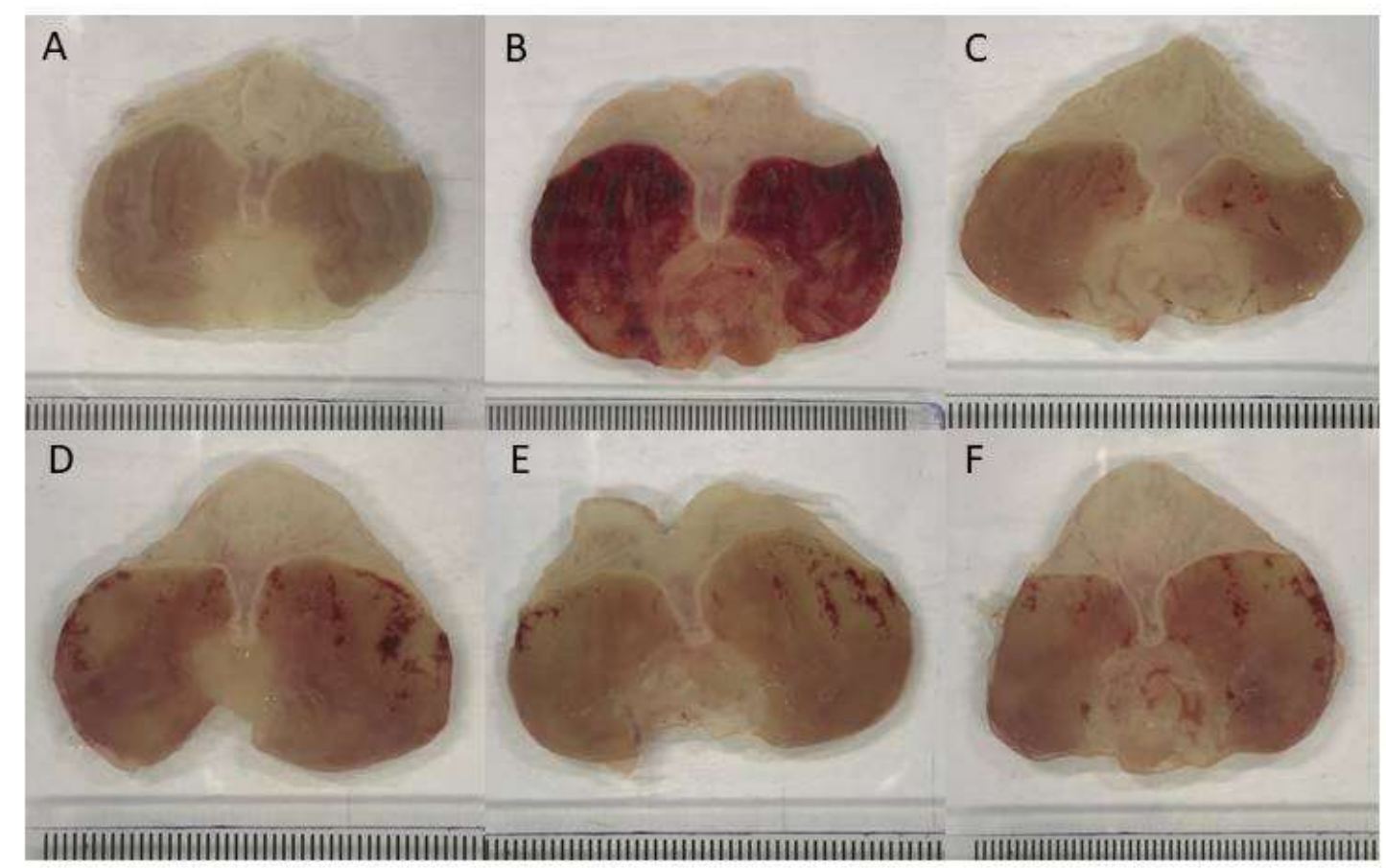

Subtitle A: Healthy control; B: Injured control; C: Lansoprazole (30 mg/kg); D: AcSm (25 mg/kg); E: AcSm (50 mg/Kg); F: AcSm (100 $\mathrm{mg} / \mathrm{kg}$ ). Source: Authors.

The gastroprotective effect of natural products may be related to the production of nitric oxide, stimulation of the antioxidant system, production of mucus and bicarbonate, prostaglandins, regeneration of gastric epithelial cells or with the inhibition of neutrophil migration and infiltration (Ateufack et al., 2015; Zhang et al., 2019).

In this work, the levels of nitric oxide, malondialdehyde, reduced glutathione and myeloperoxidase in the stomach mucosa were analyzed, as parameters of inflammation and oxidative stress. All data are shown in Table 5.

Among the main mucosal protection factors are nitric oxide and enzymatic and non-enzymatic antioxidant defense systems (Sanchez-Mendonza et al., 2019). The NO produced by the activation of nitric oxide synthase constitutively is involved in regulating the integrity of the gastric mucosa, being able to reduce motility, regulate mucus production, blood flow, and acid secretion (Antonisamy et al., 2016; Czekaj et al., 2018). In our findings, the groups pretreated with AcSm (50 and 100 $\mathrm{mg} / \mathrm{kg}$ ) showed an increase of NO levels when compared to the injured control, remaining equivalent to the value of the healthy control group. Only the dose of $25 \mathrm{mg} / \mathrm{kg}$ did not get the same result.

GSH is the main non-enzymatic antioxidant that is involved in several cellular functions and participates in oxidative metabolism, including the neutralization of hydroperoxides and maintenance of the physiological condition of proteins in the sulfhydryl groups (Beserra et al., 2011; Ali et al., 2020). When the animals were pretreated with AcSm at the three doses tested, there was an increase in GSH levels compared to the injured control, indicating a potential non-enzymatic antioxidant action. 
Table 5 - Effect of AcSm on Nitric Oxide (NO), Malondialdehyde (MDA), Reduced Glutathione (GSH) and Myeloperoxidase (MPO) levels.

\begin{tabular}{llllc}
\hline \multicolumn{1}{c}{ Groups } & \multicolumn{1}{c}{$\begin{array}{c}\text { NO } \\
(\boldsymbol{\mu m o l} / \mathbf{g} \text { tissue })\end{array}$} & $\begin{array}{c}\text { MDA } \\
(\mathbf{n m o l} / \mathbf{m g} \text { of tissue })\end{array}$ & $\begin{array}{c}\text { GSH } \\
(\boldsymbol{\mu g} / \mathbf{g} \text { of tissue) }\end{array}$ & $\begin{array}{c}\text { MPO } \\
(\mathbf{U} / \mathbf{m g} \text { of tissue })\end{array}$ \\
\hline HC & $23.97 \pm 1.23$ & $11.36 \pm 1.46$ & $725.29 \pm 45.92$ & $0.18 \pm 0.01$ \\
IC & $15.08 \pm 2.45$ & $20.50 \pm 2.25$ & $440.49 \pm 52.67$ & $0.56 \pm 0.02$ \\
Lanso & $25.38 \pm 2.36^{*}$ & $10.47 \pm 1.19^{*}$ & $736.06 \pm 46.10^{*}$ & $0.21 \pm 0.03^{*}$ \\
AcSm 25 & $16.02 \pm 2.40$ & $10.18 \pm 0.72^{*}$ & $728.87 \pm 62.94^{*}$ & $0.26 \pm 0.03^{*}$ \\
AcSm 50 & $20.82 \pm 1.79^{*}$ & $11.47 \pm 1.67^{*}$ & $741.88 \pm 51.41^{*}$ & $0.24 \pm 0.04^{*}$ \\
AcSm 100 & $22.07 \pm 1.69^{*}$ & $10.60 \pm 1.25^{*}$ & $703.11 \pm 66.56^{*}$ & $0.22 \pm 0.04^{*}$ \\
\hline
\end{tabular}

Subtitle: HC- healthy control; IC - injured control; Lanso - lansoprazole $30 \mathrm{mg} / \mathrm{Kg}$. Values are expressed as mean $\pm \mathrm{SD}$. A oneway ANOVA followed by Tukey multiple-comparisons test. * indicate $p<0.0001$ in relation to the IC group. Source: Authors.

Still observing oxidative stress parameters, we report that MDA levels in the groups treated with AcSm significantly reduced compared to the injured control. MDA is the main reaction product with thiobarbituric acid, indicating lipid peroxidation and, consequently, oxidative stress (Gulcin, 2020). In this work, the reduction in the concentration of MDA is in accordance with the data on increased levels of NO and GSH, balancing the oxidant/antioxidant system and promoting protection of the gastric mucosa.

According to Silva et al. (2014), S. maritima is composed of stemodine-type diterpenes, and Russell et al. (2011) reported that stemodine analogues have lipid peroxidation reducing properties in in vitro assays. Therefore, the effect found in this assay may be related to the phytochemical composition of this species.

Myeloperoxidase is an enzyme found in neutrophil granules. In this MPO concentration assay, it is an indirect assessment of neutrophil migration into tissue, where neutrophils are associated with increased production of pro-inflammatory cytokines (Nicolau et al., 2017). Thus, MPO levels rise in inflammatory conditions, as shown by the result of ethanol induction in the injured control group, which presented an enzyme activity level of $0.56 \pm 0.02 \mathrm{U} / \mathrm{mg}$. In the present study, AcSm $(25,50$ and $100 \mathrm{mg} / \mathrm{kg}$ ) was able to reduce MPO levels in stomachs tissue when compared to the injured control, by reducing the migration of neutrophils into the tissue.

Similar findings to these have already been reported by our group, where the hexane extract of S. maritima reduced MPO levels and increased NO and GSH levels in a gastric protection assay (Sousa et al., 2021).

\section{Conclusion}

In conclusion, the results of the current study demonstrated that ethyl acetate extract from S. maritima extract alleviated ethanol-induced gastric mucosal injury in rats by mainly increasing nitric oxide, and reducing glutathione, malondialdehyde, and myeloperoxidase levels. The extract also showed antioxidant activity in vitro in the tested methods and did not show toxicity in the tested conditions.

\section{References}

Abud, M. A., Molina, A., Wenedel, G., Juan Hikawczuk, V. E., Pelzer, L. E., \& Maria, A. O. (2012). Gastroprotective effects of Plantago major and metabolites in rats. Latin American Journal of Pharmacy, 31(8), 1203-6.

Ali, S. S., Ahsan, H., Zia, M. K., Siddiqui, T., \& Khan, F. H. (2020). Understanding oxidants and antioxidants: Classical team with new players. Journal of food biochemistry, 44(3), e13145. https://doi.org/10.1111/jfbc.13145 
Antonisamy, P., Subash-Babu, P., Albert-Baskar, A., Alshatwi, A. A., Aravinthan, A., Ignacimuthu, S., Choi, K. C., Lee, S. C., \& Kim, J. H. (2016). Experimental study on gastroprotective efficacy and mechanisms of luteolin-7-O-glucoside isolated from Ophiorrhiza mungos Linn. in different experimental models. Journal of functional foods, 25, 302-313. https://doi.org/10.1016/j.jff.2016.06.003

Ateufack, G., Mokam, E. C. D., Mbiantcha, M., Feudjio, R. B. D., David, N., \& Kamanyi, A. (2015). Gastroprotective and ulcer healing effects of Piptadeniastrum africanum on experimentally induced gastric ulcers in rats. BMC complementary and alternative medicine, 15(1), 1-10. https://doi.org/10.1186/s12906-015-0713-5

Benzie, I. F. F., \& Strain, J. J. (1996). The ferric reducing ability of plasma (FRAP) as a measure of "antioxidant power": the FRAP assay. Analytical Biochemistry, 239(1), 70-76. https://doi.org/10.1006/abio.1996.0292

Beserra, A. M. S., Calegari, P. I., Souza, M. C., Santos, R. A. N., Lima, J. C., Silva, R. M., Balogun, S. O., \& Martins, D. T. (2011). Gastroprotective and ulcer-healing mechanisms of ellagic acid in experimental rats. Journal of Agricultural and Food Chemistry,59(13), 6957-6965. https://doi.org/10.1021/jf2003267

Bradley, P. P., Priebat, D. A., Christensen, R. D., \& Rothstein, G. (1982). Measurement of cutaneous inflammation: estimation of neutrophil content with an enzyme marker. Journal of Investigative Dermatology, 78(3), 206-209. https://doi.org/10.1111/1523-1747.ep12506462

Chen, B. L., Wang, Y. J., Guo, H., \& Zeng, G. Y. (2016). Design, synthesis, and biological evaluation of crenatoside analogues as novel influenza neuraminidase inhibitors. European Journal of Medicinal Chemistry, 109, 199-205. https://doi.org/10.1016/j.ejmech.2015.12.031

Chinedu, O., \& Ibrahim, G. K. (2017). Menthol Ameliorates Secretagogue-Induced Gastric Acid Secretion in the Rat. International Journal of Current Research and Academic Review, 5(6), 113-118. https://doi.org/10.20546/ijcrar.2017.506.016

Choudhary, M. K., Bodakhe, S. H., \& Gupta, S. K. (2013). Assessment of the antiulcer potential of Moringa oleifera root-bark extract in rats. Journal of acupuncture and meridian studies, 6(4), 214-220. https://doi.org/10.1016/j.jams.2013.07.003

Cook, D., \& Guyatt, G. (2018). Prophylaxis against upper gastrointestinal bleeding in hospitalized patients. New England Journal of Medicine, 378(26), 25062516. https://doi.org/10.1056/NEJMra1605507

Czekaj, R., Majka, J., Magierowska, K., Sliwowski, Z., Magierowski, M., Pajdo, R., Ptak-Belowska, A., Surmiak, M., Kwiecien, S., \& Brzozowski, T. (2018). Mechanisms of curcumin-induced gastroprotection against ethanol-induced gastric mucosal lesions. Journal of gastroenterology, 53(5), 618-630. https://doi.org/10.1007/s00535-017-1385-3

Draper, H. H., \& Hadley, M. (1990). Malondialdehyde determination as index of lipid peroxidation. Methods Enzymol, 186, 31-421. https://doi.org/10.1016/0076-6879(90)86135-I

Dunkic, V., Kosalec, I., Joze, K. I., Potocnik, T., Cerenak, A., Zovko, K. M., Dubravka, V., Dragojevic, M. I., Kopricanec, M., Bezic, N., Srecec, S., \& Kremer, D. (2015). Antioxidant and antimicrobial properties of Veronica spicata L. (Plantaginaceae). Current drug targets, 16(14), 1660-1670.

Farrag, A. R. H., Abdallah, H. M. I., Khattab, A. R., Elshamy, A. I., Gendy, A. E. N. G. E., Mohamed, T. A., \& Hegazy, M. E. F. (2019). Antiulcer activity of Cyperus alternifolius in relation to its UPLC-MS metabolite fingerprint: a mechanistic study. Phytomedicine, 62, 152970. https://doi.org/10.1016/j.phymed.2019.152970

Green, L. C., Tannembaun, S. R., \& Goldman, P. (1981). Nitrate synthesis in the germfree and conventional rat. Science, $212(4490)$, 56-58. https://doi.org/10.1126/science.6451927

Gulcin, İ. (2020). Antioxidants and antioxidant methods: An updated overview. Archives of toxicology, 94(3), 651-715. https://doi.org/10.1007/s00204-020$02689-3$

Hampshire, V. A., \& Gilbert, S. H. (2019). Refinement, reduction, and replacement (3R) strategies in preclinical testing of medical devices. Toxicologic pathology, 47(3), 329-338. https://doi.org/10.1177/0192623318797289

Harput, U. S., Genc, Y., \& Saracoglu, I. (2012). Cytotoxic and antioxidative activities of Plantago lagopus L. and characterization of its bioactive compounds. Food and chemical toxicology, 50(5), 1554-1559. https://doi.org/10.1016/j.fct.2012.01.019

Kavitt, R. T., Lipowska, A. M., Anyane-Yeboa, A., \& Gralnek, I. M. (2019). Diagnosis and treatment of peptic ulcer disease. The American journal of medicine, 132(4), 447-456. https://doi.org/10.1016/j.amjmed.2018.12.009

Lanas, A., \& Chan, K. L. (2017). Peptic ulcer disease. Lancet, 390(10094), 613-624. https://doi.org/10.1016/S0140-6736(16)32404-7

Li, H. B., Wong, C. C., Cheng, K. W., \& Chen, F. (2008). Antioxidant properties in vitro and total phenolic contents in methanol extracts from medicinal plants. LWT - Food Science and Technology, 41(3), 385-390. https://doi.org/10.1016/j.lwt.2007.03.011

Li, W., Zhou, J., \& Xu, Y. (2015) Study of the in vitro cytotoxicity testing of medical devices. Biomedical Reports, 3(5), 617-620. https://doi.org/10.3892/br.2015.481

Liu, Z., Liu, Y., Pu, Z., Wang, J., Zheng, Y., Li, Y., \& Wei, Y. (2013). Regulation, evolution, and functionality of flavonoids in cereal crops. Biotechnology letters, 35(11), 1765-1780. https://doi.org/10.1007/s10529-013-1277-4

Moreira, H. J. C.; \& BRAGANÇA, H. B. N. (2011). Manual de identificação de plantas infestantes: Hortifrúti. São Paulo: FMC Agricultural Products.

Morimoto, Y., Shimohara, K., Oshima, S., \& Sukamoto, T. (1991). Effects of the new antiulcer agent KB-5492 on experimental gastric mucosal lesions and gastric mucosal defensive factors, as compared to those of teprenone and cimetidine. The Japanese Journal of Pharmacology, 57(4), 495-505. https://doi.org/10.1254/jjp.57.495 
Mosmann, T. (1983). Rapid colorimetric assay for cellular growth and survival: application to proliferation and cytotoxicity assays. Journal Immunological Methods, 65(1-2), 55-63. https://doi.org/10.1016/0022-1759(83)90303-4

Nicolau, L. A., Carvalho, N. S., Pacífico, D. M., Lucetti, L. T., Aragão, K. S., Véras, L. M., Souza, M. H., Leite, J. R., \& Medeiros, J. V. R. (2017). Epiisopiloturine hydrochloride, an imidazole alkaloid isolated from Pilocarpus microphyllus leaves, protects against naproxen-induced gastrointestinal damage in rats. Biomedicine \& Pharmacotherapy, 87, 188-195. https://doi.org/10.1016/j.biopha.2016.12.101

OECD. Organization for Economic Cooperation and Development (2001). Acute oral toxicity - acute toxic class method. Guidelines for the testing of chemicals, OECD 423, Section 4, OECD Publishing, Paris.

Pekal, A., \& Pyrzynska, K. (2014). Evaluation of aluminium complexation reaction for flavonoid content assay. Food Analytical Methods, 7(9), 1776-1782. https://doi.org/10.1007/s12161-014-9814-x

Prieto, P., Pineda, M., \& Aguilar, M. (1999). Spectrophotometric quantitation of antioxidant capacity through the formation of a phosphomolybdenum complex: specific application to the determination of vitamin E. Analytical Biochemistry, 269(2): 337-341. https://doi.org/10.1006/abio.1999.4019

Rodrigues, F. E., Lima, J. Q., Oliveira, M. D. C. F. D., Vasconcelos, J. N., Santiago, G. M., Mafezoli, J., Braz-Filho, R., \& Arriaga, A. (2010). Diterpene and other constituents from Stemodia maritima (Scrophulariaceae). Journal of the Brazilian Chemical Society, 21(8), $1581-1586$.

Russell, F. A., Mulabagal, V., Thompson, D. R., Singh-Wilmot, M. A., Reynolds, W. F., Nair, M. G., Langer, V., \& Reese, P. B. (2011). Stemodin-derived analogues with lipid peroxidation, cyclooxygenase enzymes and human tumour cell proliferation inhibitory activities. Phytochemistry, 72(18), 2361-2368. https://doi.org/10.1016/j.phytochem.2011.08.024

Safavi, M., Shams-Ardakani, M., \& Foroumadi, A. (2015). Medicinal plants in the treatment of Helicobacter pylori infections. Pharmaceutical biology, 53(7), 939-960. https://doi.org/10.3109/13880209.2014.952837

Sánchez-Mendoza, M. E., López-Lorenzo, Y., Cruz-Antonio, L., Matus-Meza, A. S., Sánchez-Mendoza, Y., \& Arrieta, J. (2019). Gastroprotection of calein d against ethanol-induced gastric lesions in mice: role of prostaglandins, nitric oxide and sulfhydryls. Molecules, 24(3), 622. https://doi.org/10.3390/molecules24030622

Sangeetha, M. K., Vallabi, D. E., Sali, V. K., Thanka, J., \& Vasanthi, H. R. (2013). Sub-acute toxicity profile of a modified resveratrol supplement. Food and chemical toxicology, 59, 492-500. https://doi.org/10.1016/j.fct.2013.06.037

Sedlak, J., \& Lindsay, R. H. (1968). Estimation of total, protein-bound, and nonprotein sulfhydryl groups in tissue with Ellman's reagent. Analytical Biochemistry, 25, 192-205. https://doi.org/10.1016/0003-2697(68)90092-4

Silva, F. R., Rodrigues, F. E., Gomes, A. R., Arriaga, A., Mafezoli, J., Lemos, T. L., Almeida, M. C., Santiago, G. P., Braz-Filho, R., Costa, J. G., Rodrigues, F. F. G., \& Coutinho, H. D. (2014). Phytochemical study, antioxidant and antibacterial activities of Stemodia maritima. Química Nova, $37(9)$, 1474-1478. https://doi.org/10.5935/0100-4042.20140255

Simões, S., Lopes, R., Campos, M. C. D., Marruz, M. J., da Cruz, M. E. M., \& Corvo, L. (2019). Animal models of acute gastric mucosal injury: Macroscopic and microscopic evaluation. Animal models and experimental medicine, 2(2), 121-126. https://doi.org/10.1002/ame2.12060

Song, S. H., Kim, J. E., Sung, J. E., Lee, H. A., Yun, W. B., Lee, Y. H., Song, H., \& Hwang, D. (2019). Anti-ulcer effect of Gallarhois extract with antioxidant activity in an ICR model of ethanol/hydrochloride acid-induced gastric injury. Journal of traditional and complementary medicine, 9(4), 372-382. https://doi.org/10.1016/j.jtcme.2017.07.001

Sousa, R. S., Silva, J. A. G., Borba, E. F. O., Sousa, M. G. O., Silva, S. J. L., \& da Silva, T. G. (2021). Análise fitoquímica e efeito gastroprotetor do extrato hexânico de Stemodia maritima L. Journal of Biology \& Pharmacy and Agricultural Management, 17(2).

Teixeira, A. H., Freire, J. M., de Sousa, L. H., Parente, A. T., de Sousa, N. A., Arriaga, A., Silva, F. R., Melo, I. M., Silva, I. I., Pereira, K. M., Goes, P., Costa, J. J., Cristino Filho, G., Pinto, V. P., Chaves, H. V., \& Bezerra, M. M. (2017). Stemodia maritima L. extract decreases inflammation, oxidative stress, and alveolar bone loss in an experimental periodontitis rat model. Frontiers in physiology, 8, 988. https://doi.org/10.3389/fphys.2017.00988

Vaghasiya, Y. K., Shukla, V. J., \& Chanda, S. V. (2011). Acute oral toxicity study of Pluchea arguta boiss extract in mice. Journal of Pharmacology and Toxicology, 6(2), 113-23. https://doi.org/10.3923/jpt.2011.113.123

Zakaria, Z. A., Balan, T., Azemi, A. K., Omar, M. H., Mohtarrudin, N., Ahmad, Z., \& Salleh, M. Z. (2016). Mechanism (s) of action underlying the gastroprotective effect of ethyl acetate fraction obtained from the crude methanolic leaves extract of Muntingia calabura. BMC complementary and alternative medicine, 16(1), 1-17. https://doi.org/10.1186/s12906-016-1041-0

Zhang, C., Gao, F., Gan, S., He, Y., Chen, Z., Liu, X., Fu, C., Qu, Y., \& Zhang, J. (2019). Chemical characterization and gastroprotective effect of an isolated polysaccharide fraction from Bletilla striata against ethanol-induced acute gastric ulcer. Food and chemical toxicology, 131, 110539. https://doi.org/10.1016/j.fct.2019.05.047 